\title{
Diş hekimliği eğitiminde beceri ve yeterliğin değerlendirilmesi I: Kontrol listeleri ve ölçekler
}

\author{
Funda Akaltan(0000-0001-6744-6312) ${ }^{\alpha}$ \\ Selcuk Dent J, Diş Hekimliği Eğitimini Yeniden Düşünmek - Özel Sayı
}

(Doi: 10.15311/selcukdentj.562508)

Basvuru Tarihi: 09 Mayıs 2019 Yayına Kabul Tarihi: 01 Ağustos 2019

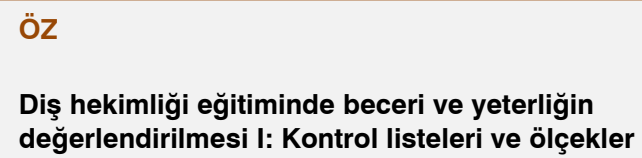

Diş hekimliği eğitiminin hedefi; mezunların güvenli, etkili ve bağımsız uygulamaları yapabilme seviyesine ulaşmalarına yardımcı olmaktır. Bu düzeydeki yeterlik; mezuniyet için gerekli minimum performans seviyesindeki akademik bilgi, klinik beceri ve profesyonel davranışların kazanımını gerektirir. Diş hekimliği eğitimindeki beceri kavramı; mesleki becerileri akla getirir. Bununla birlikte, diş hekimliği gibi meslekler için öğrencilerin sadece klinik olarak yetkin olmakla kalmayıp, topluma iyi hizmet verebilmek için iyi uyum becerilerine de sahip olmaları beklenir. Performans kontrol listeleri ve ölçekler öğrencilerin becerilerinin ölçülmesinde kullanılan araçlardır. Çok iyi bilindiği gibi, "değerlendirme öğrenimi yönlendirir" ve öğrenimin şeklini ve içeriğini programlar. Bu derleme çalışmasında, ölçme ve değerlendirme yöntemleri; kontrol listeleri ve ölçeklerin hazırlığı, kullanımı ve doğru ölçme aracının tercihi konusunda bilgi verilerek, diş hekimliği öğrencilerinin yeterlik ve becerilerinin ölçülmesinde kullanılan güncel uygulamalar konusunda farkındalık oluşturulmaktadır.

\section{ANAHTAR KELIMELER}

Diş hekimliği eğitimi, değerlendirme, kontrol listesi, ölçek

\begin{abstract}
Assessment of skill and competence in dental education I: Control lists and rubrics

The goal of dental education is to facilitate the development of an individual to a level where they are capable of safe, effective and independent practice. This degree of competency comprises academic knowledge, clinical skills and professional attitudes and factors that define the minimum acceptable performance level for a dentist at the time of graduation. Skills in dental education are mainly described as professional psychomotor skills. However, students in a professional undergraduate program such as dentistry are expected to not only be clinically competent upon graduation but also to exhibit good soft skills in order to serve the society at large. Performance checklists and rubrics can help educators to define students' skills in ways that are specific to the work context and provide a way to record how well learners demonstrate these skills and competencies. It is a general assumption that 'assessment drives learning' through its format, content and programming. Preparing, using and choosing the right rubric and/or checklist and also the assesment and evaluation methods are discussed in this review study to help educators to assess the competencies and the skills of their dental students.
\end{abstract}

\section{KEYWORDS}

Dental education, assessment, controllist, rubric

Öğrencilere kazandırıması amaçlanan öğrenmeler içerisinde bilişsel-düşünsel-kavramsal-teorik (cognitive, thinking), duyuşsal-duyusal-duygusal (affective, emotion/feeling) ve psikomotor-devimsel-fiziksel (psychomotor, physical/kinesthetic) özellikler içeren kazanımlar yer almaktadır., ${ }^{1,2}$

\section{Beceri ve Yeterliğin Anlamı}

Beceri; belirli bazı motor fonksiyonların veya araç gerecin belli bir düzeydeki ustalıkla belirli bazı görevleri yerine getirebilmek üzere kullanımasıdır. Beceri kavramı yeterlik ile birlikte ifade edilir. ${ }^{1}$

\footnotetext{
${ }^{\alpha}$ Ankara Üniversitesi Diş Hekimliği Fakültesi, Protetik Diş Tedavisi Anabilim Dalı, Ankara
} 
Yeterlik (competence/competency); belli şartlar altında bir becerinin belli standartlara uygun olarak yapılabilmesidir. ${ }^{1,2}$ Bilgi, beceri ve davranışların mesleğin bireysel yönlerine uygun olarak karışımıdır. Mezun diş hekiminin sahip olması gereken minimum kabul edilebilir performans seviyesini gösterir. ${ }^{3}$

Performans; beceri ve yeterlik ile birlikte sözü edilen bir terimdir; kişisel davranışların bir karışımıdır ve dış faktörlerden etkilenir. ${ }^{4}$ Diş hekimliğinde ise performans; spesifik durumlarda spesifik bir yetenek örneği veya yeterliklerin önde gelen beceri bileşeni olan psikomotor davranış olarak tanımlanır. ${ }^{5}$ Performans iyi veya kötü olarak gözlenebilirken, yeterlik becerinin önceden belirlenmiş seviyesidir. Sonuçta performans sadece beceri veya yetenek üzerinde odaklanır ve yeterliğin sadece bir kısmıdır.

Yeterlik; bağımsız diş hekimliği uygulamalarına hazırlanan bireyin beceriler, anlama ve profesyonel değerleri olarak tanımlanmıştır. ${ }^{6}$ Diş hekimliği eğitiminin esas amacı; hem öğrenciler hem de hastalar için güven oluşturarak, profesyonel olarak yetkin sağlık çalışanları yetiştirmektir. ${ }^{3}$

Yeterliklerin tanımlanması süreci zorlayıcıdır ve diş hekimliğindeki birçok konuda henüz yeterlikler oluşturulamamıştır. Yeterliklerin tanımlanması için literatürde 3 yaklaşım vardır: ${ }^{7}$

1. Davranış bilimleri yaklaşımına dayanarak yeterlik; bir görevi yerine getirebilme yeteneğidir; ölçülebilir davranışlara odaklanır. Bu yaklaşımın çok basit olduğu düşünülerek eleştirilir; çünkü yeterliği davranışa indirgemek; yeterliğin düşünsel, duygusal ve içeriksel yönlerini göz ardı eder.

2. Kökenine özgü ve daha kapsamlı bir bakış açısıyla yeterlik; bireylerin görünmeyen profesyonel davranışlarını kapsar; ancak bu yaklaşım; değerlendirme ve diğer içeriklere geçişi zor olan internal davranışlara odaklanır.

3. Bu eleştirilerin çözümlenmesi için bütüncül (holistic) bir yaklaşım önerilmiş; yeterliğin içerikle ve "bilgi, beceri, davranış, performans ve yeterli olma düzeyleri" ni içeren alt davranışlarla ilişkili olarak anlaşılması gerektiği ileri sürülmüştür. Bu kompleks yapının anlaşılması yine de yeterliğin değerlendirilmesini güç kılar.

Yeterlik komplekstir ve direkt olarak ölçülemez; genellikle de yeterliği temsil eden bir yetenek örneği olarak değerlendirilir. ${ }^{5}$ Yeterliğin bilgi, profesyonel ve etik davranışlar, yansıma uygulamaları (reflection-bilgiyi başka alanlarda kullanabilme) gibi diğer yönleri inmal edilebilir; yalnızca performansa odaklanmak, yeterliği tam anlamılla temsil edemez. Diş hekimliği eğitiminde yeterliği değerlendirmek için hangi yöntemlerin uygun olduğu, bu nedenle hala tartışma konusudur.

Diş hekimliğinde beceri kavramı; öncelikle mesleki becerileri akla getirir. Mezun diş hekimlerinin sadece mesleki (klinik) beceriler için yeterlik kazanmakla kalmayıp, topluma iyi hizmet sunabilmeleri için iyi uyum becerilerine sahip olmaları da gerekir. Klinik, bilimsel ve çevreyle uyum becerileri dental müfredatın önemli bileşenleri olarak tanımlanır; zira bu şekilde öğrenciler hastalarını empati anlayışı ile dinleyip, sorgulayabilir ve sonuçta hastaların da kendi ağız sağığı durumları ve intiyaçlarını anlamalarına yardımcı olurlar. ${ }^{8}$

Uyum becerileri (soft skills); öğrencilerin motive olması için önemlidir; ki bunlar öğrencileri gelecekte eleştirel düşünerek ve amaçları doğrultusunda harekete geçmeleri için cesaretlendirecektir. ${ }^{8}$ Uyum becerileri; (1) iletişim, (2) düşünme ve problem çözme, (3) takım çalışması gücü, (4) hayat boyu öğrenme ve bilgi yönetimi, (5) girişimci, (6) etik, ahlak ve profesyonellik (7) liderlik becerileri olarak tanımlanmıştır. ${ }^{8,9}$ 
Diş hekimliği öğrencilerinin kavramsal-algısal-düşünsel olmayan (noncognitive) becerilerinin başarılarına olan etkileri birçok araştırmaya konu olmuştur. ${ }^{10-14}$ "Kavramsal olmayan" terimi; akademik değerlendirmeler ile sıklıkla ölçülen, algı yeteneğinin karşıı olarak, öğrenci başarısına katkı sağlayabilecek kişisel özellikler, sosyo-duygusal faktörler, tutum ve davranışı tanımlamak için kullanılmaktadır. ${ }^{15-17}$

Öğrencilerin başarıına katkı sağlayan ve eğitmenler tarafından algılanan kavramsal olmayan faktörlerin belirlenmesi ve bu faktörlerin akademik performans, klinik performans ve genel başarıya olan etkilerinin değerlendirilmesi amacıyla yapılan bir araştırmada ${ }^{14}$; 2015-2016 senelerinde Birleşmiş Milletler'de bir fakültedeki 184 nitelikli eğitmen içinden 43 tanesi yer almıştır. Eğitmenler, öğrenci başarısına etki eden kavramsal olmayan faktörleri; iletişim/bireylerarası ilişki becerileri, öğrenme yaklaşımı, kişisel özellikler, profesyonellik, zıt deneyimler ve teknik yetenekler olarak tanımlamış; akademik performans için hazırbulunuşluk, klinik performans için ise iletişim özeliğinin önemli olduğunu belirtmişlerdir.

\section{Ölçme ve Değerlendirme Nedir?}

Bir eğitim sisteminin başarısı hakkında geri bildirim veren en önemli özellik öğrencilerin kazandıkları davranışlar ya da bilgi ve becerilerdir.

Ölçme, bir niteliğin gözlenip, gözlem sonucunun sayı ya da sembollerle gösterilmesidir. ${ }^{18}$ Değerlendirme ise, elde edilen ölçme sonuçlarından bir anlam çıkarmak için söz konusu ölçümlerin bir ölçüt ile karşılaştırılması ve bu yolla bir değer yargısına ulaşımasıdır. ${ }^{18,19}$

Cronbach ${ }^{20}$ değerlendirmenin eğitimdeki rolünü şöyle ifade etmektedir. Değerlendirme;

• öğrenciye davranışı nasıl değiştireceği ve nasıl geliştireceği hakkında bilgi verir;

- yeterince başarılı olan öğrenciyi güdüler;

- öğrenci hakkında verilecek kararlara dayanak olur;

- eğitmene, öğretimin ne derece etkili olduğunu görmesine yardımcı olur;

- ilgililere bilgi (geri bildirim) verir.

\section{Öğrenmenin Değerlendirilmesi}

Değerlendirmenin esas amacı; (1) motivasyon ve yönlendirme yaparak, öğrencilerin yeteneklerini en iyi şekilde kullanmak, (2) gelecekte öğrenmelerini desteklemek için lisans eğitimindeki kendi kendini değerlendirmeyi anlamak, (3) toplumu yetkin olmayan klinisyenlerden uzak tutmak ve (4) ileri eğitim için adayları seçmek üzere bir temel oluşturmak şeklinde özetlenmiştir. ${ }^{21}$

Değerlendirme; öğrenme boşluklarını tanımlamaya yardımcı olmak, geleceğe yönelik öğrenmeyi şekillendirmek ve yansıma uygulamalarını desteklemek için yapılan, izlemeye dayalı durum belirleme (formative) veya öğrenme dönemi sonunda öğrenmeyi, bilgi ve yeterliği değerlendirmek için kullanılan, düzey belirleme (summative) şeklinde olabilir. ${ }^{22}$ Her değerlendirme yönteminin kendine özgü güçlü ve zayıf tarafları mevcuttur ve bu eksiklikleri gidermek için zaman içinde farklı değerlendirme yöntemlerinin bir arada kullanılması önerilir. 
Düzey belirleyen değerlendirme; öğrencilerin öğrenimini, eğitim döneminin sonunda bazı standartlar veya kriterlerle kıyaslayarak değerlendirir. Düzey belirleyen değerlendirmeler; basamaklıdır ve genellikle spesifik bir sınav hazırlamayı teşfik eder; böylece öğrencilerin öğrenme davranışlarını değiştirir ve yönlendirir. Bir seneden diğerine ilerlemeyi görmek ve sınıf geçmek gibi ödül için kullanılan değerlendirmedir. ${ }^{3}$

İzlemeye dayalı değerlendirme; eğitmenlerin kendi eğitim yöntemlerini, öğrencilerin ise öğrenmelerini iyileştirmeleri için sürekli geri bildirim üretmek ve öğrencinin öğrenmesini izlemek için kullanılır. Öğrencilerin performanlarıyla ilgili geri bildirim aldıkları, ileri dönem gelişmelerine fırsat tanıyan bir yöntemdir. ${ }^{3}$ Geri bildirim; özellikle izlemeye dayalı değerlendirmede, etkili değerlendirmenin vazgeçilmez bileşenidir. Açık ve anlaşılır olmalıdır; aksi halde faydalı olamaz.

İzlemeye dayalı değerlendirmeyle sonuç başarı yerine, öğrenmede gelişim hedeflenerek, "hedeflenen başarıdan da büyük başarılar olduğu" na odaklanmak gerekir. İzlemeye dayalı değerlendirmeler basamaklı değildir ve başarısızılk oluşturmaz; aksine bu değerlendirmeler öğrencilerin gelecekteki çalışma alışkanlıklarını yönlendirecek olan bir geri bildirim sağlar. Ayrıca kişinin kendi bilgisini denetlemesi; hatta bilginin uzun dönem saklanmasına yardımcı olur. ${ }^{3}$ İzlemeye dayalı durum belirleyen değerlendirmelerle kolaylaştıılan sınavla-geliştirilen öğrenim; bilgi ve becerinin pekiştirilmesi amacıyla kullanılmıştır. ${ }^{23-26}$ Sınav sırasında yapılan telafi uygulamalarının bağımsız çalışmalara göre bilgi ve beceriyi daha kalııı kıldığı, ${ }^{27}$ bilgiyi hatırlama ve çalışma alışkanlıklarını düzenleme üzerinde de etkili olduğu ${ }^{28}$ bildirilmektedir.

İzlemeye dayalı değerlendirme; öğrenci başarısını arttıran ve kendini yansıtan bir işlemdir. Öğrenmeyi iyileştiren, farkındalığı arttıran ve cevaplayan, eğitmen ve öğrenci arasındaki iki yönlü bir süreç olarak tanımlanır. Öğrenme aktivitelerinden alınan geri bildirim; öğretimin öğrenenlerin ihtiyaçlarına adapte etmek için kullanıldığında; değerlendirme "izlemeye dayalı durum belirleme" olarak kabul edilir; öğrenciler bu sayede öğrenimlerinin kontrolünü kendileri sağlar (kendi kendini düzenleyen öğrenme-self-regulated learning) ${ }^{2}$

Çok iyi bilindiği gibi, değerlendirme öğrenimi yönlendiririr,29 ve iletişim gibi uyum becerilerini öğretmek kadar değerlendirmek de önemlidir. Bu nedenle iletişim konusunda müfredat çalışmaları yapılırken, hem öğretme hem de değerlendirme göz önünde tutulmalıdır. ${ }^{30}$ Avrupa'daki okullarda öğrencilerin iletişim becerilerinin değerlendirilmesi çoğunlukla izlemeye dayalı durum belirleme (\% 29) daha az oranda (\% 15) düzey belirleme şeklinde yapılmaktadır. İzlemeye dayalı ve düzey belirleyen değerlendirmeler arasındaki farklar ${ }^{3}$

1. Değerlendirmenin yapıldığı zaman: İzlemeye dayalı değerlendirme eğitim süresince, düzey belirleyen sürecin sonunda yapilır.

2. Değerlendirme stratejisi: İzlemeye dayalı değerlendirmede; öğrenim sürecinde öğrenci izlenerek, yardıma intiyacı olup olmadığı belirlenir. Düzey belirlemede ise çalışmasına puan verilir. Puanlar; öğrencinin öğrenim hedefine ulaşıp ulaşmadığını bildirir.

3. Amaç: İzlemeye dayalı değerlendirmede öğrencinin öğrenme düzeyini iyileştirmek amaçlanır ve bunu başarabilmek için anlamlı geri bildirimler yapmak gerekir. Diğerinde amaç; öğrenci başarısını değerlendirmektir. Öğrencinin bir konuda en iyi olmasını mı, yoksa eğitim sürecinde kendini sürekli daha iyileştirmesini mi istediğinize karar vermeniz gerekir. 
4. Değerlendirme işleminin kapsamı: İzlemeye dayalı değerlendirme; öğrenim sürecinde birkaç kere tekrarlanır. Ör; bir ders için 3 izlemeye dayalı değerlendirme yapıır. Düzey belirleyen değerlendirmede tüm dersi kapsayan sınav yapılır; ders materyalinin kapsamı çok geniştir.

5. İzlemeye dayalı değerlendirme; durumu bir süreç olarak ele alır. Eğitmen öğrencinin gelişimini görebilir ve öğrencinin öğrenme düzeyini yukarıya doğru yönlendirir. Düzey belirleyen değerlendirmede öğrenciyi yukarıya doğru gelişmeye yönlendirmek daha güçtür. Değerlendirme tek seferde yapııır ve biter. Bu nedenle de düzey belirleyen değerlendirme "sonuç" olarak düşünülür.

Değerlendirme yönteminin tercihinde 5 adet anahtar kriter mevcuttur:29

1. Güvenirlik: Değerlendirmenin doğruluk ve tekrar edilebilirlik derecesidir.

2. Geçerlik: Değerlendirmenin amaçladığını ölçüp ölçememesidir.

3. Gelecek öğrenme ve uygulamalar üzerindeki etkisi

4. Öğrenciler ve eğitmenler tarafından kabul edilebilirliği

5. Maliyeti: Bireysel olarak öğrenciye, kuruma ve genel olarak topluma

Değerlendirme öğrenmeye yön verirken, aynı zamanda yanlış anlaşılan ve tartışmalı bir araç olabilir; çünkü öğrencilerin intiyaçlarını karşılarken kendi kendine yönlendirilebilir. ${ }^{31}$ Her değerlendirmenin istenmeyen bazı etkileri de mevcuttur. Değerlendirme yöntemleri sıklıkla subjektif, çelişkili ve yanlış anlaşılabilen, "göz at ve puanla" gibi tek yönlü eğitmen değerlendirmelerini kullanır. ${ }^{22}$ Değerlendirmelerin çoğu yaşam boyu öğrenme, eleştirel düşünme ve yansıma uygulamalarını dikkate almaz. Tek amacı sınavı geçmek olan ezberci öğrenimi cesaretlendirir. Değerlendirme sistemlerinin bazıları öğrencilerin kendi öğrenimlerini iyileştirmelerine fırsat vermez; çünkü değerlendirme; bir sonraki aşama için başlangıç olmak yerine gelinen son nokta olarak düşünülür. ${ }^{32}$

\section{Güvenirlik ve Geçerlik Kavramları}

Güvenirlik; elde edilen sonuçların hassasiyeti ve yoğunluğunu kapsar. Değerlendirme işlemindeki spesifik, anlaşılır kriterler ve test edilen becerilerin çok yönlü örneklemesiyle geliştirilebilir. Bir ölçme aracının güvenirliğini, o ölçme aracından elde edilen puanların (ölçme sonuçlarının) hatalardan arınıklık derecesi belirler. ${ }^{33}$ Bir ölçme aracından elde edilen puanlara ne kadar az hata karışırsa, araç o derece güvenilirdir. Ölçme aracından elde edilen sonuçlar, bireyler arasında var olan öğrenme farklılıklarını gösterdiği ölçüde ya da bireylerin var olan gerçek öğrenme güçlerini ortaya koyduğu ölçüde güvenilirdir.

Gerçeklik; ölçmek istenenle ölçülen arasındaki uyumdur. Bir ölçme aracının geçerliğini; o ölçme aracının amacını gerçekleştirme düzeyi, belli bir işe yarama derecesi oluşturur. Bir ölçme aracı amacını ne derece gerçekleştiriyorsa o kadar geçerlidir. Örneğin, bir eğitim süreci sonunda sınav yapmanın amacı, o süreçte kazandırımaya çalışılan davranışların, kazanııı kazanılmadığını ortaya koymaktır. Kısaca geçerlik, bir ölçme aracının ölçmeyi amaçladığı özelliği başka özelliklere karıştırmadan, doğru olarak ölçebilme derecesidir. ${ }^{18,19}$

Diş hekimliği pratiğinin önemli bir bileşeni olan klinik becerilerin değerlendirilmesinin geçerli ve güvenilir olması gerekir. Öğretim sürecinde istenen öğrenme çıktılarına ulaşııp, ulaşılamadığını belirlemenin en etkili yolu, sürecin uygun ölçme araçlarıyla izlenmesi ve elde edilen bulgulara dayalı olarak etkin kararlar alınmasıdır. Kararların 
isabetliliği, kullanılacak ölçme araçlarının güvenirlik ve geçerlik özellikleriyle son derece ilgilidir. Kullanılacak ölçme araçlarının bireylerin öğrenmeleri hakkında doğru kararlar vermesi ve amaca hizmet eden sonuçlar ortaya koyması önemlidir. ${ }^{1,2}$

\section{Ölçme Araçları: Kontrol Listeleri ve Ölçekler}

Günümüzde özellikler hakkında doğru bilgiler elde etmenin en etkili yolu, o özelliğin ayrıntılarını ortaya çıkaracak hassas gözlem araçları kullanmaktır. ${ }^{34}$ Bilişsel, duyuşsal ve devimsel özelliklerin de ölçülmesinde ölçme araçları kullanılmaktadır. Her zaman ölçülmesi düşünülen bir özelliğe uygun ölçme aracı bulunmaz. Böyle durumlarda ölçülecek özellik üzerinde çalışan alan uzmanları, ölçek geliştirme süreci hakkında bilgi sahibi olan ölçme ve değerlendirme uzmanlarıyla ya da psikometrislerle birlikte çalışmakta ve özellik hakkında güvenilir, geçerli bilgiler ortaya koyacak bir ölçek geliştirmektedirler. Bu nedenle ölçme aracı geliştirme süreci, ölçülecek özelliğin doğru tanımlanmasından, o özelliği ölçecek aracın belirlenmesine, aracı geliştirme, uygulama ve analiz etme hatta ölçme sonuçlarının kullanılma yollarının bilinmesine kadar ustalık gerektiren aşamaları içerir. ${ }^{35}$

Becerilerin ölçülmesi için performans kontrol listeleri ve ölçekler kullanılır. ${ }^{34}$ Kontrol listeleri; bir davranışın varlığı veya yokluğunu ölçer. İkili yapıdadır; doğru-yanlış veya evet-hayır seçeneklidir. Kontrol listesi; davranışın kalitesini vermez; sadece varlığını gösterir (Şekil 1 ve Şekil 3). Ölçekler ise öğrencinin davranışı sergileme derecesini gösterir. Ölçekler bir skalaya bağlıdır (Şekil 2, Şekil 4 ve Şekil 5) ve her skalanın sahip olduğu durumlar veya özellikler tarif edilmiştir (Şekil 6). ${ }^{19}$

Değerlendirilen kişi:

Değerlendirici:

Tarih:

Yeterlik (beceri):

\section{DAVRANIŞLAR}

\section{$\mathbf{D} / \mathbf{Y}$}

ÖNERILER

\begin{tabular}{|l|l|l|}
\hline Davranış 1 & & \\
\hline Davranış 2 & & \\
\hline Davranış 3 & & \\
\hline
\end{tabular}

Öğrencinin imzası:

Gözlemcinin imzası:

Şekil 1. Performans Kontrol Listesi ${ }^{34}$

\section{Kontrol listeleri ve ölçeklerin faydaları}

Becerilerin ölçülmesi için kontrol listelerini ve ölçekleri kullanmanın bazı faydaları vardır: ${ }^{34}$

1. Beceride ustalığı gösterecek davranış özelliklerini ve beceriyi destekleyecek davranışları tanımlar.

2. Öğrencilerin eğitim intiyaçları olup olmamasını belirlemek için de kullanılır. Eğitim sürecinde, öğrencilerin nasıl geliştikleri konusunda geri bildirim vermek için, eğitim sonunda ise öğrencilerin istenen ustalık derecesine ulaşıp ulaşmadıklarını ölçmek için kullanııır. 
Gözlemlenen kişi:

Değerlendirici:

Tarih:. Yeterlik (beceri)

\begin{tabular}{|l|l|l|l|}
\hline DAVRANIŞLAR, HAREKET, ÖZELLIK & & & \\
\hline Davranış 1 & & & \\
\hline Davranış 2 & & & \\
\hline Davranış 3 & & & \\
\hline
\end{tabular}

Öğrencinin imzası:

Gözlemcinin imzası:.

Şekil 2. Performans Ölçeği34

\section{Kontrol listeleri ve ölçeklerin geliştirilmesi}

Becerilerin ölçülmesi için bu araçların geliştirilmesinde 6 basamak izlenir: ${ }^{18}$

1. İstenen beceride usta olan ve zayıf özellik sergileyen kişiler seçilir.

2. İşinde usta ve başarısız olan kişiler sorgulanır.

3. Ustalara; beceriyi etkili kılan davranışların neler oldukları sorgulanır.

4. Ustalara; daha az başarıı kişilerden farklı olarak nasıl davranış sergiledikleri sorgulanır.

5. İstenen davranışların ve özelliklerinin bir listesi çıkarııı.

6. Bu liste kontrol listesi veya ölçek olarak kullanılır.

\section{Kontrol listeleri ve ölçeklerin yapısı}

Her ikisinin de 2 kısmı mevcuttur: İlk kısım; başlıktır ve ölçülecek becerinin ismini içerir; değerlendirilecek kişinin adı ve soyadı; değerlendiren kişinin adı ve soyadı; tarih ve değerlendirme yapılan yeri kapsar. Gerektiğinde, beceriyi gerçekleştirmek için kullanılacak araç gereçler, uygulamada dikkat edilecek noktaları içeren kısa talimatlar ve uygulama için gerekli süre de ölçek formuna ilave edilir. Her iki araçta da değerlendiren için talimatlar vardır; başlama ve bitiş sürelerini yazmaları için boş yer bırakılır (Şekil 1- Şekil 5). ${ }^{34}$

Araçların online kullanımında; demografik sorular da eklenebilir. Demografik özellikler; kişilerin spesifik özelliklerinin davranışa etkisini ortaya çıkarmak için faydalıdır. Demografik sorular; öğrencinin ne kadar süre eğitim aldığı, ne tip bir eğitim aldığı, eğitimi ne zaman tamamladığı, eğitimi kimden aldığı, ne kadar tecrübeye sahip olduğu, bu tecrübeye ne zaman sahip olduğu ve deneyime kimin önderlik ettiğini içerebilir. ${ }^{344}$ 
İkinci kısım; tablodur. Her ikisinde de ilk sütun; ölçülmek istenen becerinin veya yeterliğin ismini içerir. Beceriyi destekleyen davranışların listesini de içerebilir. Kontrol listelerinde; bir sütun öğrencinin davranışı gösterip göstermediği, diğerinde ise öneriler için kullanılır. Ölçekte ise; öğrencinin davranışı hangi seviyede gösterdiğini tanımlayan ilave sütunlar vardır (Şekil 1). ${ }^{34}$

Öğrenci adı soyadı/numarası.

Tarih:
Ĕ̆itmen:

Beceri: Fonksiyonel kaşık hazırlığı (Otopolimerizan)

\begin{tabular}{|c|c|}
\hline DAVRANIŞLAR & $\mathbf{D} / \mathbf{Y}$ \\
\hline 1. Anatomik model alçı motoru ile kesilerek şekillendirilir. & \\
\hline 2. Soğuk akrilik hamuru ölçeklenerek hazırlanır. & \\
\hline 3. Soğuk akrilik hamurunun uygun kıvama gelmesi beklenir. & \\
\hline 4. Anatomik model üzerinde protez hudutları kırmızı kalemle çizilir. & \\
\hline 5. Protez hudutlarından $1 \mathrm{~mm}$ kısa olan kaşık hudutları, modelde sabit kalemle çizilir. & \\
\hline 6. İki tabaka pembe mum, modele homojen şekilde ve kaşık hudutları içinde yerleştirilir. & \\
\hline 7. Mum üzerinde stop bölgeleri (dişler ve birinci molar dişler bölgesinde-3 adet) hazırlanır. & \\
\hline 8. Mum dışında kalan bölgelere izolan madde sürülür. & \\
\hline 9. Stop bölgeleri, soğuk akrilik hamur parçaları yerleştirilerek doldurulur. & \\
\hline 10. Akrilik hamuru tabaka halinde şekillendirilir. & \\
\hline 11. Kaşık sapı için bir miktar hamur ayrılır. & \\
\hline 12. Tabaka soğuk akrilik hamuru, homojen kalınlıkta rölyef mumu üzerine yerleştirilir. & \\
\hline 13. Akrilik hamurundan taşanlar, kaşık sınırlarına göre spatülle kesilerek uzaklaştırılır. & \\
\hline 14. Kaşık sapı için bant şeklinde akrilik hamuru hazırlanır. & \\
\hline 15. Kaşık sapı uygun konumda ve şekilde monte edilir. & \\
\hline 16. Sertleşmesi tamamlanan akrilik kaşık, modelden uzaklaştırılır. & \\
\hline 17. Akrilik kaşığın doku yüzeyinden pembe mum artıkları spatül yardımıyla temizlenir. & \\
\hline 18. Kaşık hudutları canavar veya möl yardımıyla düzeltilir. & \\
\hline 19. Kaşığın dişli bölgelerine daha büyük çapta veya daha çok sayıda delik açılır. & \\
\hline 20. Kaşığın dişsiz kret bölgelerine daha küçük çapta veya daha az sayıda delik açılır. & \\
\hline 21. Deliklerin aljinatın ayrılmasını önleyecek çapta, konumda ve sayıda olması sağlanır. & \\
\hline 22. Hazırlanan deliklerdeki çapaklar (iç ve dış yüzeydeki akrilik çıkıntılar) temizlenir. & \\
\hline 23. Kaşığın dış yüzeyi, sapı ve kenarları pürüzsüz olacak şekilde zımparalanır. & \\
\hline 24. Model üzerinde kalan pembe mum artıkları uzaklaştırılır. & \\
\hline 25. Anatomik model temizlenir. & \\
\hline 26. Fonksiyonel ölçü kaşığı model üzerinde konumlandırı & \\
\hline
\end{tabular}

Şekil 3. Fonksiyonel Kaşık Hazırlığı Için Kontrol Listesi 
Öğrenci adı soyadı/numarası.

Tarih:
Ĕ̆itmen:

Beceri: Fonksiyonel kaşık

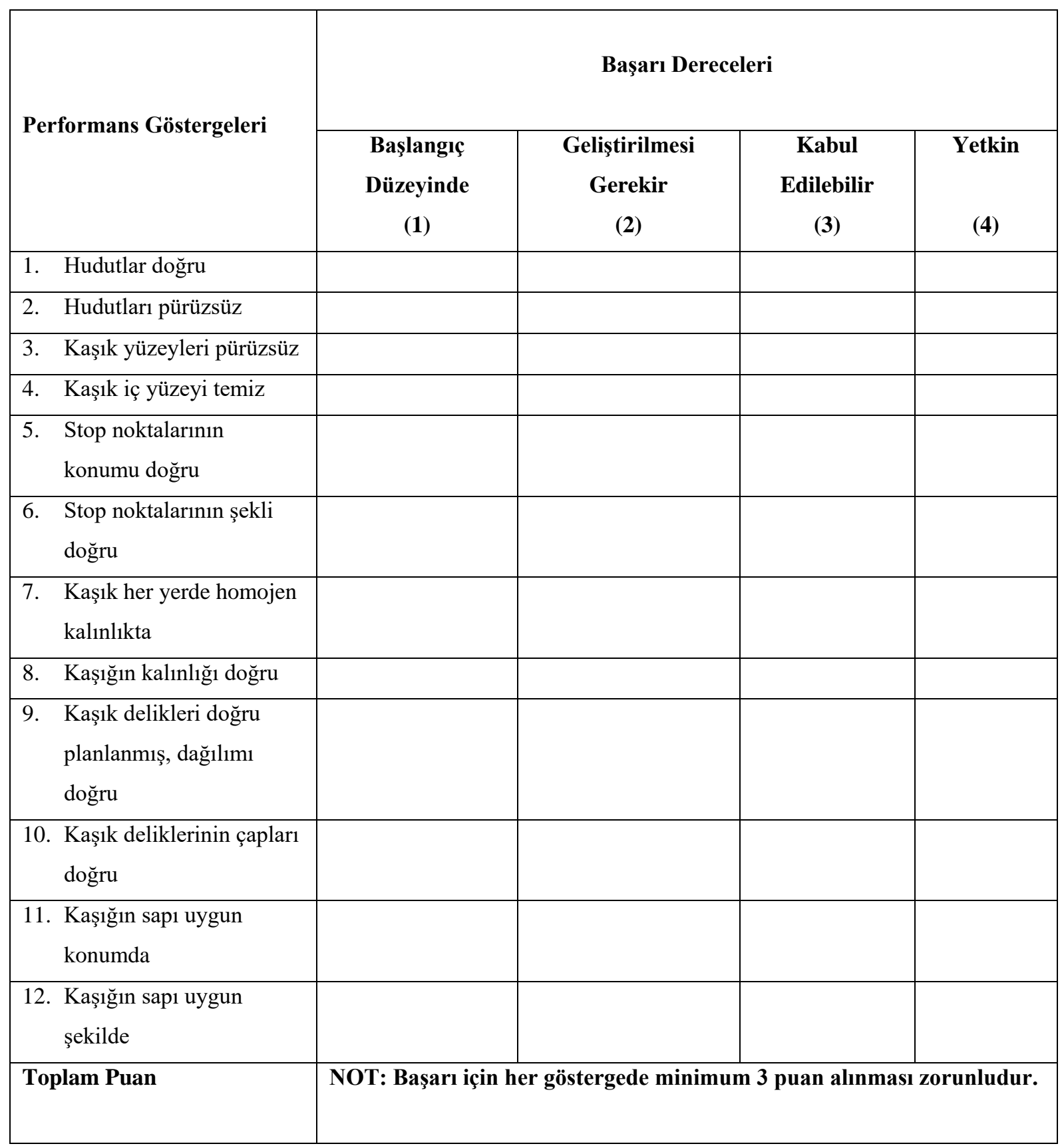

Öğrencinin imzası:

Gözlemcinin imzası:.

Şekil 4.a) Fonksiyonel Kaşık İçin Değerlendirme Ölçeği 
Öğrenci adı soyadı/numarası.

Tarih:
Ĕ̆itmen:

Beceri: Fonksiyonel kaşık

\begin{tabular}{|c|c|c|c|c|}
\hline \multirow{2}{*}{$\begin{array}{l}\text { Performans } \\
\text { Göstergeleri }\end{array}$} & \multicolumn{4}{|c|}{ Başarı Dereceleri } \\
\hline & $\begin{array}{c}\text { Başlangıç Düzeyinde } \\
\text { (1) }\end{array}$ & $\begin{array}{l}\text { Geliştirilmesi } \\
\text { Gerekir } \\
\text { (2) }\end{array}$ & $\begin{array}{c}\text { Kabul Edilebilir } \\
\text { (3) }\end{array}$ & $\begin{array}{l}\text { Yetkin } \\
\text { (4) }\end{array}$ \\
\hline 1. Kaşık şekli & $\begin{array}{l}\text { Hudutlar eksik veya } \\
\text { uzun; pürüzlü; kalılılık } \\
\text { yetersiz veya fazla, } \\
\text { homojen değil; yüzey } \\
\text { pürüzlü. Zayıf kalite; } \\
\text { yetersiz çaba göstergesi; } \\
\text { dört veya beş tane hata } \\
\text { var. }\end{array}$ & $\begin{array}{l}\text { Hudutlar kısmen } \\
\text { doğru ve pürüzlü, } \\
\text { kalınlık kısmen doğru, } \\
\text { yüzey homojen, yüzey } \\
\text { ve hudutlar kısmen } \\
\text { pürüzsüz. Orta } \\
\text { düzeyde çaba } \\
\text { göstergesi; üç veya } \\
\text { dört hata var. }\end{array}$ & $\begin{array}{l}\text { Hudutlar doğru ve } \\
\text { pürüzsüz, kalılılık } \\
\text { doğru, yüzey } \\
\text { homojen, yüzey ve } \\
\text { hudutlar pürüzsüz. } \\
\text { İyi çaba göstergesi }\end{array}$ & $\begin{array}{l}\text { Hudutlar doğru ve } \\
\text { pürüzsüz, kalınlık } \\
\text { doğru, yüzey } \\
\text { homojen, yüzey } \\
\text { ve hudutlar } \\
\text { pürüzsüz. } \\
\text { Üst düzey çaba } \\
\text { göstergesi }\end{array}$ \\
\hline 2. Kaşık iç yüzeyi & $\begin{array}{l}\text { Stopların şekli ve } \\
\text { konumu hatalı, iç yüzey } \\
\text { pürüzlü. } \\
\text { İki veya üç hata var. }\end{array}$ & $\begin{array}{l}\text { Stopların şekli ve } \\
\text { konumu kısmen } \\
\text { doğru, iç yüzey orta } \\
\text { düzeyde pürüzsüz. } \\
\text { Genel olarak kusurlu } \\
\text { görünümde }\end{array}$ & $\begin{array}{l}\text { Stopların şekli ve } \\
\text { konumu doğru, iç } \\
\text { yüzey pürüzsüz. } \\
\text { Hatalar büyük } \\
\text { anlamda dikkat } \\
\text { çekmiyor. }\end{array}$ & $\begin{array}{l}\text { Stopların şekli ve } \\
\text { konumu doğru, iç } \\
\text { yüzey pürüzsüz. } \\
\text { Hatasız iç yüzey }\end{array}$ \\
\hline 3. Kaşık delikleri & $\begin{array}{l}\text { Kaşık delikleri vakaya } \\
\text { ve ölçü malzemesine } \\
\text { göre doğru } \\
\text { planlanmamış, çapı ve } \\
\text { sayısı yanlış; delikler } \\
\text { çapak içeriyor. } \\
\text { Üç veya dört hata var. }\end{array}$ & $\begin{array}{l}\text { Kaşı delikleri vakaya } \\
\text { ve ölçü malzemesine } \\
\text { göre doğru } \\
\text { planlanmış, çapı ve } \\
\text { sayısı kısmen doğru, } \\
\text { delikler çapak } \\
\text { içeriyor. } \\
\text { Üzerinde çalışılması } \\
\text { gerekir. }\end{array}$ & $\begin{array}{l}\text { Kaşık delikleri } \\
\text { vakaya ve ölçü } \\
\text { malzemesine göre } \\
\text { doğru planlanmış, } \\
\text { çapı ve sayısı doğru, } \\
\text { delikler çapaksız. } \\
\\
\text { İyi çaba göstergesi }\end{array}$ & $\begin{array}{l}\text { Kaşık delikleri } \\
\text { vakaya ve ölçü } \\
\text { malzemesine göre } \\
\text { doğru planlanmıs, } \\
\text { çapı ve sayısı } \\
\text { doğru, delikler } \\
\text { çapaksız. } \\
\text { Üst düzey çaba } \\
\text { göstergesi }\end{array}$ \\
\hline 4. $\quad$ Kaşısk sapı 1 & $\begin{array}{l}\text { Kaşık sapının şekli, } \\
\text { kalınlığı, eğimi ve } \\
\text { konumu yetersiz. } \\
\text { Üç veya dört hata var. }\end{array}$ & $\begin{array}{l}\text { Kaşık sapının şekli, } \\
\text { kalınlığı, eğimi ve } \\
\text { konumu kısmen } \\
\text { doğru. } \\
\text { Orta düzeyde çaba } \\
\text { göstergesi; iki veya üç } \\
\text { hata var. }\end{array}$ & $\begin{array}{l}\text { Kaşıłk sapının şekli, } \\
\text { kalınlığı, eğimi ve } \\
\text { konumu doğru. } \\
\text { İyi çaba göstergesi }\end{array}$ & $\begin{array}{l}\text { Kaşık sapının } \\
\text { şekli, kalınlığı, } \\
\text { eğimi ve konumu } \\
\text { doğru. } \\
\text { Üst düzey çaba } \\
\text { göstergesi }\end{array}$ \\
\hline
\end{tabular}

Öğrencinin imzası:

Gözlemcinin imzası:

Şekil 4.b) Fonksiyonel Kaşık İçin Değerlendirme Ölçeği 


\section{Klinik Uygulama Becerilerine Yönelik Ölçek Hazırlama}

Uygulamanın yapılması sırasında izlenen yolun ölçülmesi: Öğrenci kendisinden beklenen beceriyi yerine getirirken, eğitmen bu becerinin nasıl yerine getirildiğini adım adım izler ve önceden tanımlanmış olan kendi içinde aşamalı her adıma birer puan verir ya da o becerinin gözlenip gözlenemediğini ölçek veya kontrol listesi üzerinde ayrılan yere çek atarak işaretler (Şekil 5). ${ }^{19}$

Uygulamada;

- belirlenen yolun ayrıntılarıyla izlenip izlenmediği,

- işi yaparken uygun malzemenin seçilip seçilmediği,

- işi yaparken malzemenin doğru kullanılıp kullanılmadığı,

- iş ortamının ve malzemelerin doğru organize edilip edilmediği

gözlenir. Bu işleme, "sürecin ölçülmesi ve değerlendirilmesi" denir.

\begin{tabular}{|c|c|c|c|c|c|}
\hline \multirow[b]{2}{*}{$\begin{array}{l}\text { Sürece İlişkin Performans } \\
\text { Göstergeleri }\end{array}$} & \multicolumn{4}{|c|}{ Başarı Düzeyleri } & \multirow[b]{2}{*}{$\begin{array}{l}\text { Başarı } \\
\text { Puanı }\end{array}$} \\
\hline & $\begin{array}{l}\text { Başlangıç } \\
\text { Düzeyinde } \\
\text { (1) }\end{array}$ & $\begin{array}{l}\text { Geliştirilmesi } \\
\text { Gerekir } \\
\text { (2) }\end{array}$ & $\begin{array}{c}\text { Kabul } \\
\text { Edilebilir } \\
\text { (3) }\end{array}$ & $\begin{array}{l}\text { Yetkin } \\
\text { (4) }\end{array}$ & \\
\hline $\begin{array}{l}\text { 1. Hastayı karşıılama, ünite alma } \\
\text { ve konumlandırma }\end{array}$ & & & & & \\
\hline $\begin{array}{l}\text { 2. Gereken malzemeleri eksiksiz } \\
\text { olarak ünite getirme }\end{array}$ & & & & & \\
\hline 3. İşlem öncesi elleri yıkama & & & & & \\
\hline $\begin{array}{l}\text { 4. Hasta önlüğü, maske, eldiven } \\
\text { takma }\end{array}$ & & & & & \\
\hline $\begin{array}{l}\text { 5. Hastayı işlem süreci } \\
\text { konusunda bilgilendirme, } \\
\text { onam alma }\end{array}$ & & & & & \\
\hline $\begin{array}{l}\text { 6. Protezi ağıza yerleştirmeden } \\
\text { önce kontrol etme }\end{array}$ & & & & & \\
\hline $\begin{array}{l}\text { 7. Protezi ağıza uygun konumda } \\
\text { yerleştirme }\end{array}$ & & & & & \\
\hline $\begin{array}{ll}8 . & \text { Protezin kaide sınırlarını ve } \\
\text { dokularla uyumunu kontrol } \\
\text { etme ve varsa gereken } \\
\text { düzenlemeleri yapma }\end{array}$ & & & & & \\
\hline $\begin{array}{l}\text { 9. } \begin{array}{l}\text { Protezin okluzyonunu } \\
\text { uyumlandırma }\end{array}\end{array}$ & & & & & \\
\hline $\begin{array}{l}\text { 10. Kroşe konumlarını ve } \\
\text { tutuculuklarını kontrol etme, } \\
\text { gerekirse uyumlandırma }\end{array}$ & & & & & \\
\hline
\end{tabular}




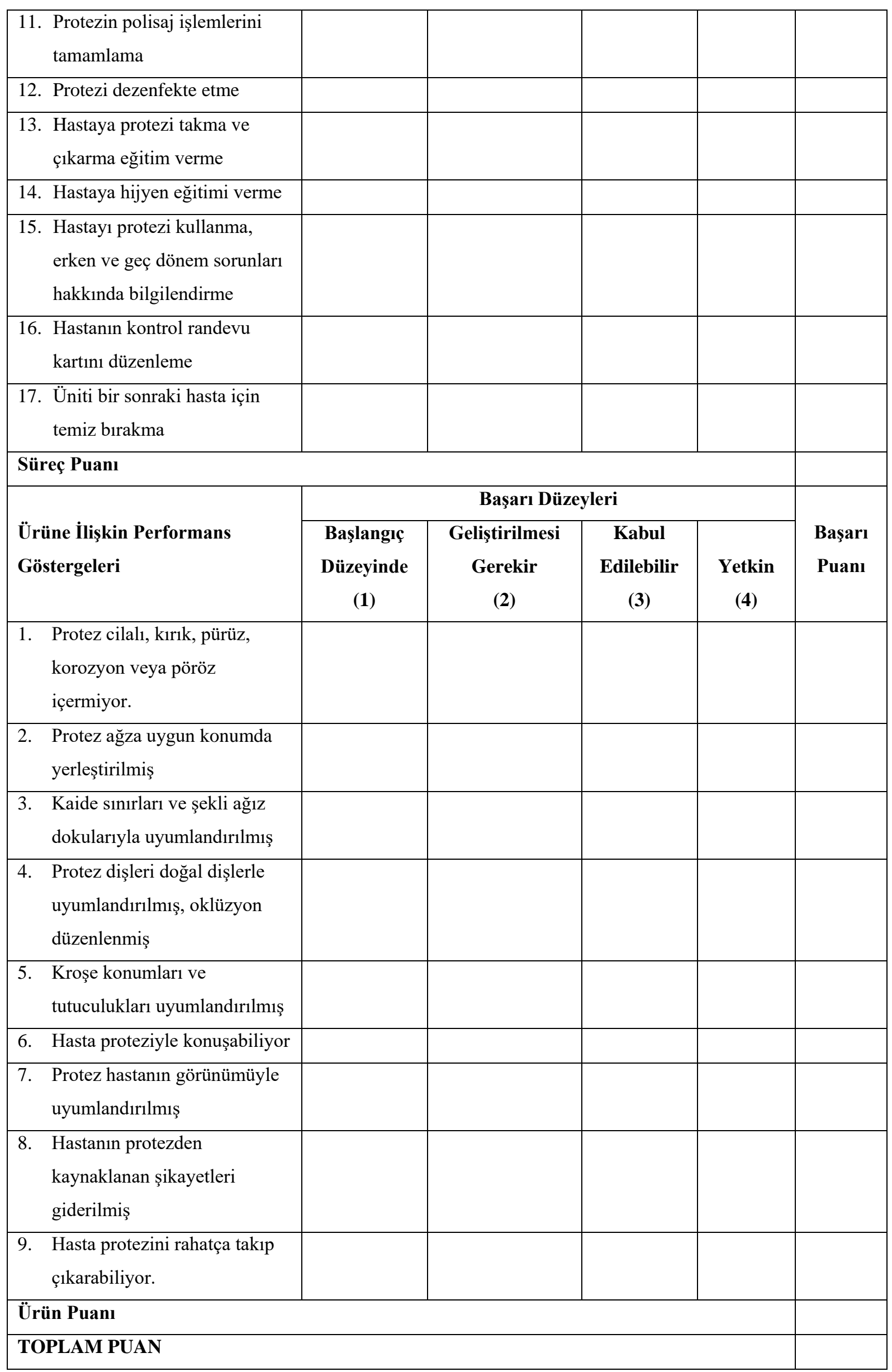

Şekil 5. Hareketli bölümlü protezin ağıza uyumlandırılması ölçeği (süreç ve ürüne ait) ${ }^{19}$ 


\begin{tabular}{|c|c|c|c|c|}
\hline Kategori & 3 puan & 2 puan & 1 puan & O puan \\
\hline İçerik & $\begin{array}{l}\text { İyi dokümanlanmış } \\
\text { ve organize } \\
\text { edilmiş. } \\
\text { Mükemmel } \\
\text { açılama; üst düzey } \\
\text { çaba göstergesi }\end{array}$ & $\begin{array}{l}\text { Oldukça iyi } \\
\text { dokümanlanmış ve } \\
\text { organize edilmiş. } \\
\text { Kolay izlenir } \\
\text { formatta. İyi } \\
\text { düzeyde açıklama; } \\
\text { iyi çaba göstergesi }\end{array}$ & $\begin{array}{l}\text { Kısımlar zayıf } \\
\text { dokümanlanmış } \\
\text { veya organize } \\
\text { edilmiş. İzlemesi } \\
\text { güç; açıklama orta } \\
\text { düzeyde çaba } \\
\text { göstergesi }\end{array}$ & $\begin{array}{l}\text { Organize olmamış. } \\
\text { İzlenemez } \\
\text { durumda. Zayıf } \\
\text { kalite; yetersiz çaba } \\
\text { göstergesi }\end{array}$ \\
\hline Yazılı Döküman & $\begin{array}{l}\text { Doğru gramer, } \\
\text { yazım, imla, büyük } \\
\text { harfler; hatasız } \\
\text { yazım. }\end{array}$ & $\begin{array}{l}\text { İki veya üç gramer } \\
\text { veya imla ve yazım } \\
\text { hatası mevcut; } \\
\text { hatalar büyük } \\
\text { anlamda dikkat } \\
\text { dağıtmıyor. }\end{array}$ & $\begin{array}{l}\text { Üç veya dört } \\
\text { gramer veya imla } \\
\text { ve yazım hatası } \\
\text { mevcut; hatalar } \\
\text { okuyucunun } \\
\text { dikkatini dağıtıyor. }\end{array}$ & $\begin{array}{l}\text { Dört veya beş hata } \\
\text { mevcut; yazıda } \\
\text { okuyucunun aklını } \\
\text { karıştıracak kadar } \\
\text { çok hata var. }\end{array}$ \\
\hline Organizasyon & $\begin{array}{l}\text { İçerik iyi organize } \\
\text { olmuş; başlıklar ve } \\
\text { imlemeler grupları } \\
\text { iyi tanımlamış }\end{array}$ & $\begin{array}{l}\text { Organize etmek } \\
\text { için başlık ve } \\
\text { imlemeler } \\
\text { kullanılmış; fakat } \\
\text { başlıkların } \\
\text { organizasyonu } \\
\text { genel olarak } \\
\text { kusurlu görünümde }\end{array}$ & $\begin{array}{l}\text { Başlık eksiği var; } \\
\text { tüm bölümler } \\
\text { mantıklı organize } \\
\text { edilmemiş }\end{array}$ & $\begin{array}{l}\text { Açık ve mantıklı } \\
\text { organize edilmiş } \\
\text { bir yapı yok; } \\
\text { sadece bir sürü } \\
\text { unsur var. }\end{array}$ \\
\hline $\begin{array}{l}\text { Farklı } \\
\text { Multimedya }\end{array}$ & $\begin{array}{l}\text { Bilginin tümü } \\
\text { farklı elektronik } \\
\text { veya elektronik } \\
\text { olmayan kaynaktan } \\
\text { alınmış }\end{array}$ & $\begin{array}{l}\text { Bilginin çoğu farklı } \\
\text { elektronik veya } \\
\text { elektronik olmayan } \\
\text { kaynaktan alınmış }\end{array}$ & $\begin{array}{l}\text { Bilginin bir kısmı } \\
\text { farklı elektronik } \\
\text { veya elektronik } \\
\text { olmayan kaynaktan } \\
\text { alınmış }\end{array}$ & $\begin{array}{l}\text { Bilginin hiçbiri } \\
\text { farklı elektronik } \\
\text { veya elektronik } \\
\text { olmayan kaynaktan } \\
\text { alınmamış }\end{array}$ \\
\hline İnandırıcı Bilgi & $\begin{array}{l}\text { Kanıt geniş } \\
\text { seçenekli gerçek } \\
\text { kaynaklardan } \\
\text { alınmış }\end{array}$ & $\begin{array}{l}\text { Kanıt birçok gerçek } \\
\text { kaynaklardan } \\
\text { alınmış }\end{array}$ & $\begin{array}{l}\text { Gerçek kaynaklar } \\
\text { tutarsızca } \\
\text { kullanılmış }\end{array}$ & $\begin{array}{l}\text { Bilgi kısmen } \\
\text { gerçek } \\
\text { kaynaklardan } \\
\text { alınmış }\end{array}$ \\
\hline
\end{tabular}

Şekil 6. Sunum Becerileri Ölçeği ${ }^{34}$

Uygulama bitiminden sonra ortaya çıkan ürün kalitesinin ya da sonucun ölçülmesi: Öğrenci kendisinden istenen beceriyi yerine getirir ve bir ürün ortaya koyar. Eğitmen bu ürünü tanımlanmış ölçütler (ölçü ve doğruluk standartları) açısından inceler ve bir puan verir (Şekil 5). ${ }^{19}$

Ürünün;

- istenen özelliklere sahip olup olmadığı,

- önceden belirlenen ölçütlere ya da standartlara ne derece sahip olduğu, 
- sahipse ne derece kusursuz olarak sahip olduğu

gibi özelliklerine bakılarak puan verilir. Bu işleme, "ürünün ölçülmesi ve değerlendirilmesi” denir.

Öğrenci kendisinden istenen beceriyi yerine getirerek bir ürün ortaya koyar. Eğitmen hem becerinin nasıl gerçekleştirildiğini hem de ürünün nasıl olduğunu inceler ve bir puan verir. Bu işleme, "sürecin ve ürünün ölçülmesi ve değerlendirilmesi" denir.

\section{Ölçmede İzlenen Aşamalar}

Dolaylı olarak ölçülebilen bilişsel ve duyuşsal özelliklere göre devimsel özellikler çoğunlukla doğrudan ölçülebilmektedirler. Devimsel becerilerin ölçülmesinde izlenecek adımların doğru tanımlanmış olması sürecin daha nesnel gözlenmesine yardımcı olacaktır.

Ölçülecek davranış ve davranış özelliklerine karar verilmesi: Sürecin en önemli aşamalarından biri ölçülecek davranışların hangileri olduğuna karar vermektir. Bunun için en uygun yol, ölçülecek ilgili becerinin ayrıntılı olarak analiz edilmesidir. Daha sonra bu ayrıntılı döküm içerisinden, süreç ve hedef açısından önemli olan "kritik davranışlar" belirlenir. Bir sonraki aşama ise, bu kritik davranışların aşamalı olarak sıralanmasıdır. Bu sıralama sırasında becerilerin kendi içindeki öncelik-sonralık sırası dikkate alınmalıdır. ${ }^{18,19}$

Kritik davranışların belirlenmesi sırasında karar verilmesi gereken önemli noktalardan birisi de, bir beceriyi istenen yeterlikte yapamayan bir öğrencinin işleme devam edip etmeyeceği kararının verilmesidir. Özellikle sağlık alanındaki klinik uygulamalarda, öğrencinin bir aşamadaki beceriyi belli bir yeterlik düzeyinde yapamaması ve işlemi sürdürmesi durumunda hasta zarar görebilecektir. Böyle bir durumda, ilgili beceriyi ölçmek amacıyla geliştirilmiş aracın yönergesine bu durumun belirtilmesi yerinde olacaktır. ${ }^{19}$

Kullanılacak ölçme aracına karar verilmesi: Kontrol listesi bir psikometrik ölçme aracı tasarlamanın ve uygulamanın en kolay yoludur. ${ }^{36}$ Kontrol listeleri, ölçme sürecinde öncelik-sonralık ilişkisine göre sıraya konmuş davranışlardan hangilerinin yapılıp hangilerinin yapılmadığını, belirli işlem yollarının izlenip izlenmediğini belirlemek ya da olumlu ve olumsuz yapılan davranışların sayısını kaydetmek amacıyla kullanılmaktadır. Kontrol listeleri ölçme aracı olarak kullanıldığı gibi, bir beceriyi oluşturan davranışların nasıl ve hangi sırada yapıldığını, hangi işlem yollarının izlenmesi gerektiğini göstermek amacıyla öğretim sırasında, "öğrenim rehberi” olarak da kullanılmaktadır. Kontrol listeleri genellikle sürecin ölçülmesi durumunda ve izlemeye dayalı değerlendirme için kullanılan ölçme araçlarıdır. ${ }^{19}$

Dereceleme ölçeği, bir davranışın yapılıp yapılmadığından ya da olumlu-olumsuz yapıldığından çok "ne düzeyde" ya da "hangi yetkinlik düzeyinde" yapıldığı hakkında bilgi verir.

Ölçekler davranışlar için bir skala içerir. Ölçekler için en az 3 derecelendirme olmalıdır; aksi halde ölçek yerine iki seçenekli, kontrol listesi özelliği taşır. Skaladaki derecelendirmenin sayısı; davranışların birbirinden ne kadar iyi derecede ayırd edilmesinin tercihiyle alakalıdır; ancak derecelerin sayısı artıkça, ölçeği oluşturmak zorlaşır. Skalanın nasıı sıralayacağına karar vermek gerekir. Bazıları en iyi davranış özelliği ile başlar ve en kötüsüyle bitirirken, diğerleri tersini yapar. Her iki yöntem de skala boyunca tutarlı ve istikrarlı olmalıdır. Ölçeklerde yetkinlik düzeyi genellikle en basitten en yetkine doğru; örneğin $1-2-3-4-5$ gibi belirtilirken, yargı içeren bir ifadeyle de örneğin "gözlenemedi", "yetersiz", "orta yeterlikte", "yeterli”, "çok yeterli” şeklinde belirtilebilir. ${ }^{19,34}$ 
Skala ile ilişkili olarak, her bir dereceye kaç puan verileceğine de karar vermek gerekir. Puanların miktarı; sonuçların nasıl kullanacağına bağlıdır. Bu konuda tek bir doğru cevap yoktur. En önemlisi, her davranış için minimum puan beklentisinde mi veya sadece ortalama bir skor elde etmek mi istendiğine karar vermektir. Ör; öğrenci bir davranış konusunda zayıf performans gösterdiğinde yine yeterli kabul edilebilir mi? Bu sorunun cevabı; sonuçları nasıl kullanacağınız ile ilişkilidir. Ölçeğin eğitim süresince geri bildirim olarak kullanılması planlandığında, öğrencilere harekete bağı geri bildirim kazandırma üzerinde yoğunlaşmak gerekir. Katılımcıların davranışı iyileştirmek için neyi çalışması gerektiği ortaya konulur. Ölçeğin öğrencilerin istenen seviyede yeterlik elde edip etmediğine karar vermek için kullanılmasında, ortalama skor elde etmek amaçlanabilir. ${ }^{19,34}$

Ölçme aracının alan uzmanlarınca gözden geçirilmesi: Hazırlanan ölçeklerin, bu alanda çalışan başka uzmanlarca da gözden geçirilmesi yerinde olacaktır. ${ }^{18,19}$ Bu süreçte ölçeğe yeni bir göz olarak bakan uzmanlar;

- ölçeğin kapsam açısından uygun olup olmadığını,

- bilimsel hatalar taşıyıp taşımadığını,

• ölçmek istediği özellikleri başka özelliklere karıştırmadan ölçüp ölçmediğini,

- basamaklar arasındaki öncelik-sonralık sırasının doğruluğunu,

- yazım ve anlatım dilinin Türkçe dil kurallarına uygunluğunu

• ölçeğin uygun biçimde düzenlenip düzenlenmediğini

denetleyerek, önerilerde bulunacaklar ve ölçeğin daha yetkin duruma gelmesine katkıda bulunacaklardır.

Ölçme aracının ön denemesinin yapılması: Uzman denetimlerinin yanı sıra, ölçeği uygulamada kullanmadan önce benzer özelliklere sahip bir grupta ön denemesini yapmak, ön deneme uygulamasından elde edilen puanlara dayanarak ölçeğin güvenirliği ve geçerliği için kanıtlar elde etmeye çalışmak yerinde olacaktır. Bunun için araştırmacı, ölçeği aynı gruba belirli aralıklarla iki kez uygulayarak, iki uygulama arasındaki kararılığa (test-tekrar test güvenirliği) bakabilir; güvenirlik için bir kanıt elde etmeye çalışabilir. Ayrıca eğer varsa, aynı becerileri ölçen bir testle birlikte uygulayarak iki uygulama arasındaki ilişkiye bakabilir; bu kez de geçerlik için bir kanıt elde etmeye çalışabilir. Yine uygulama kapsamına giren öğrencilerin yakın alandaki dersleriyle ilişkisine bakabilir ve bulduğu sonucu geçerliğin bir ölçüsü olarak kullanabilir. ${ }^{18,19,35,37}$

Performans kontrol listeleri veya ölçekleri hazırlamak; özellikle kompleks ve kişilerarası becerilerde paydaşlar arasındaki diyaloğu kolaylaştıır; varsayımlar ve çelişkilerle yüzleşmeyi sağlar. Tanımlar yapıldıktan sonra; güvenirlik ve geçerlik üzerinde tartışma ve değerlendirmeler yapııır. Hazırlık sürecinin sonunda, hangi davranışların yeterlikle daha fazla ilişkide olduğu ve hangi özelliklerin yeterlik için kanıt oluşturduğu konularında ortak görüşe ulaşılır. ${ }^{18,19}$

Ölçme aracının kullanımına yönelik eğitim: Kontrol listesi veya ölçeğe sahip olduğunuzda, insanların becerileri değerlendirmek için bu araçları nasıl kullanacakları konusunda eğitilmeleri de önemlidir. ${ }^{18}$

Ölçme araçlarından elde edilen sonuçların değerlendirilmesi: Öğrenmelerin ölçülmesindeki temel amaç, ölçmeye konu olan özelliklerden yararlanarak bireyler hakkında karar vermektir. Bu nedenle, karar vermede ölçme işlemi tek başına yeterli değildir; değerlendirme işleminin devreye girmesi gerekir. ${ }^{18,19}$ 
Değerlendirme işleminin doğruluğu öncelikle ölçme sonuçlarının doğruluğuna, sonra da uygun ölçütün seçilmiş olmasına bağlıdır. Ölçüt seçimi öğretimden beklenen amaca göre değişebilir. Değerlendirme ölçütü, nota dayanılarak verilecek kararın isabet derecesini artırmalı, karar vermeyi kolaylaştırmalıdır. Değerlendirme sürecinde "mutlak ölçüt” ve "bağı̈l ölçüt” olmak üzere iki grup ölçüt kullanılır. ${ }^{18,19}$

Mutlak değerlendirme; öğrencinin başarısını, önceden belirlenmiş belli bir standartla karşılaştıır. Bu tür ölçütler; değerlendirilen öğrenci grubundan, ölçekten ve ölçeği uygulayan kişiden bağımsızdır. Örneğin, okullarımızda belirlenmiş geçme sınırları mutlak ölçüte bir örnektir; 100 puan üzerinden 60 puan alanın geçmesi gibi. Mutlak ölçüte göre not vermede öğrencilerin bireysel farklılıkları dikkate alınmaz. ${ }^{18,19}$

Bağıl değerlendirme; ölçütün grubun ya da ölçeğin özelliklerine bağlı olarak seçildiği durumlarda kullanılır ve öğrencinin başarısı grupta yer alan diğer bireylerin başarısıyla karşılaştıııır. Değerlendirme puanlarından elde edilen aritmetik ortalamanın üstünde not alanların geçmesi bu duruma bir örnektir. Bağıl değerlendirme; öğrencilerarası bireysel farklııkların açığa çıkmasına katkıda bulunan bir değerlendirme yoludur. ${ }^{18,19}$

Cologne Üniversitesi'nde hasta-hekim iletişimine yönelik kanıta dayalı bir müfredat geliştirilmiş ve 2009 yıında uygulanmaya başlamıştır. ${ }^{38}$ iletişim konusundaki bu müfredat; öğrencilerin hasta-hekim iletişiminin farklı yönleriyle baş edebilmeleri için gerekli ve çok yönlü elemanları kapsamaktadır. ${ }^{39}$ İletişim konusunda kanıta dayalı bu müfredatın; toplum ve iletişim becerilerini karşılamak üzere öğrencilerin tutumları üzerindeki etkisini değerlendirmek amacıyla bir çalışma ${ }^{38}$ yapılmış; tıp öğrencilerinin iletişimi öğrenmelerini ölçmek için, Rees ve ark.ları ${ }^{40}$ tarafından geliştirilen bir iletişim becerisi tutum ölçeği kullanılmıştır. Bu ölçek daha sonra Laurence ve ark.ları ${ }^{41}$ tarafından geliştirilerek diş hekimliği öğrencileri için uygun hale getirilmiştir. Ölçek; pozitif ve negatif olmak üzere iki farklı tutumda yer alan maddelerden oluşmaktadır: ${ }^{41}$

I. Pozitif tutumlar (positive attitude scale=PAS)

1. Öğrenciler; iletişim becerilerini öğrenmenin hem hastaları hem meslektaşlarıyla kişilerarası iletişim becerilerini kolaylaştırdığına inanır.

2. Öğrenciler; iletişim becerilerini öğrenmenin eğlenceli ve ilginç olduğuna inanır.

3. Öğrenciler; iletişim becerilerini öğrenmenin eğitimde önemli bir içerik olduğuna inanır.

II. Negatif tutumlar (negative attitude scale=NAS)

1. Öğrenciler; iletişim becerilerini öğrenmenin sosyal bilimlerle ilgili bir tutum olduğuna inanır.

2. Öğrenciler; iletişim becerilerini öğrenme konusunda umursamaz davranır.

3. Öğrenciler; iletişim becerilerini öğrenmenin zor olduğuna inanır.

4. Öğrenciler; iletişim becerilerinin ölçülemeyeceğine inanır.

İletişim becerilerine yönelik olan müfredatın; iletişim becerilerinin öğrenilmesi konusunda öğrencilerde azalan negatif ve artan pozitif tutumların gelişimine neden olduğu vurgulanmıştı. ${ }^{38}$

Alman diş hekimliği öğrencilerinin (1) iletişim yeterliği, (2) takım yeterliği, (3) öğrenme yeterliği ve (4) bilim yeterliği oranlarını elde etmek için 11 fakülteyi kapsayan bir çalışma ${ }^{42}$ yapılmış; Freiburg anketi (Freiburg Questionnaire to Assess Competencies in Medicine-FCM)'nin çalışmayla ilgili 4 kısmı uygulanmıştır. Anketteki her madde için, 
katıımcıların güncel yeterlik seviyeleri ve meslekleri için gerekli olduğunu düşündükleri yeterlik seviyesi sorgulanmıştır. Öğrencilerin mevcut yeterlik performanslarının, meslekleri için beklenen performanslarından daha düşük olduğu görülmüştür. ${ }^{42}$ Çalışmaya dahil olan fakültelerden gelen eğitmenlere de yukarıda belirtilen 4 gruptaki yeterliğe ait öğrenme hedeflerinin kendi okullarındaki eğitimde yer alıp almadığı sorgulanmış; okulların \% 19'unda tamamiyle, \%55.4'ünde kısmen karşılandığı ve \% 25'inde hiç karşılanmadığı gözlenmiştir. Almanya'daki müfredatın değerlendirilen yeterlikleri karşılaması açısından, gözden geçirilmesi gerektiği vurgulanmıştır.

\section{SONUÇ}

İyi bir değerlendirme stratejisinin hedefi; program boyunca etkili değerlendirme gösterebilmesi; değerlendirmenin geliştirilmesinde ve uygulanmasında öğrenciler ve eğitmenlerin yer alması gerekir. Değerlendirme çıktıları; öğrenciler için bir sıçrama tahtası niteliğinde olup, mezuniyet sonrası yaşam boyu öğrenme, bağımsız ve yansıma uygulamaları için olumlu bir yaklaşım sunar. Sağlık bilimleri ve klinik diş hekimliğindeki hızıı bilgi gelişimi; eğitim programı ve değerlendirmenin birlikte ele alınmasını gerektirir. Herşeyin öğretilmesi ve değerlendirilmesi mümkün değildir; bu nedenle de öğrencilerin mezuniyette yeterliklerine ulaşabilmelerini sağlamak için örnekleme yönteminin kullanılması avantaj sağlar. Fakültelerin; bu nedenle tüm öğrencilerinin başarıı olmaları gereken çekirdek elemanlarını tespit etmeleri beklenir. Yeterlik ve becerilerin değerlendirilmesinde; subjektif, çelişkili ve yanlış anlaşılabilen, "göz at ve puanla" gibi tek yönlü eğitmen değerlendirmeleri günümüz standartlarına ulaşmada artık yeterli değildir.

Kontrol listeleri ve ölçekler; öğrencilerin fakülte öğretim elemanlarıyla aynı kriterleri kullanarak kendi kendilerini değerlendirmelerine olanak sağlayan, öğrencilerin farkındalığını ve öğrenimleriyle ilişkili eleştirel düşünmelerini motive eden bir mekanizma oluşturur. Etkili öğretmeyi kolaylaştırarak, öğretim becerilerini iyileştirir; değerlendirme yapanlar arasındaki tutarılığı teşfik eder ve öğrenciler için detaylı geri bildirim oluşturur. 


\section{KAYNAKLAR}

1. Albino JE, Young SK, Neumann LM, Kramer GA, Andrieu SC, Henson L. Assessing dental students' competence: best practice recommendations in the performance assessment literature and investigation of current practices in predoctoral dental education. J Dent Educ 2008; 72: 1405-35.

2. Bertoli E, Lawson KP, Bishop SS. Dental Students' Skills Assessments: Comparisons of Daily Clinical Grades and Clinical and Laboratory Assessments. J Dent Educ 2018;82: 417-23.

3. Plasschaert AJM, Manogue M, Lindh C, McLoughlin J, Murtomaa H, Nattestad A et al. Curriculum content, structure and ECTS for European dental schools. Part II: methods of learning and teaching, assessment procedures and performance criteria. Eur J Dent Educ 2007; 11: 125-36.

4. Khan K, Ramachandran S. Conceptual framework for performance assessment: competency, competence and performance in the context of assessments in healthcare - deciphering the terminology. Med Teach 2012; 34: 920-8.

5. Chambers DW, Glassman P. A primer on competency-based evaluation. J Dent Educ 1997; 61: 651-66.

6. Chambers DW. Some problems in problem-based learning. J Dent Educ 1995; 59: 567-72.

7. McMullan M, Endacott R, Gray MA, Jasper M, Miller CM, Scholes J. Portfolios and assessment of competence: a review of the literature. J Adv Nurs 2003: 41: 283-94.

8. Gonzalez MAG, Abu Kasim NH, Naimie Z. Soft skills and dental education. European J Dent Educ, 2013; 17: 73-82.

9. Quieng MC, Lim PP, Lucas MRD. 21st Century-based Soft Skills: Spotlight on Non-cognitive Skills in a Cognitiveladen Dentistry Program. European Journal of Contemporary Education, 2015; 11: 71-81.

10. Hannah A, Lim BT, Ayers KMS. Emotional intelligence and clinical interview performance of dental students. J Dent Educ 2009; 73: 1107-17.

11. Schönwetter DJ, Wener ME, Mazurat N. Determining the validity and reliability of clinical communication assessment tools for dental patients and students. J Dent Educ 2012; 76: 1276-90.

12. Ihm JJ, Lee G, Kim KK, Janq KT, Jin BH. Who succeeds at dental school? Factors predicting students' academic performance in a dental school in Republic of Korea. J Dent Educ 2013; 77: 1616-23.

13. Stacey DG, Kurunathan TM. Noncognitive indicators as critical predictors of students' performance in dental school. J Dent Educ 2015; 79: 1402-10.

14. Virtue SM, Pendergast L, Tellez M, Waldron E, Ismail A. Identifying noncognitive skills that contribute to dental students' success: dental faculty perspectives. J Dent Educ 2017; 81: 300-9.

15. Borghans L, Duckworth LE, Heckman JJ, Weel B. The economics and psychology of personal traits. J Human Resourc 2008; 43: 972-1059. 
16. Rosen JA, Glennie EJ, Dalton BW, Lennon J, Bozick RN. Noncognitive skills in the classroom: new perspectives on educational research. Research Triangle Park, NC: RTI International, 2010.

17. García E. The need to address noncognitive skills in the education policy agenda. EPI Briefing Paper \#386. Washington, DC: Economic Policy Institute, 2014.

18. Turgut MF, Baykul Y. Eğitimde ölçme ve değerlendirme. 6. Baskı. Ankara, Pegem Akademi Yayıncılık, 2014.

19. Akaltan F, Akçam MO, Öztan M, Gökalp H, Görgün S, Günhan M ve ark.ları. Diş Hekimliğinde Klinik Becerilerin Ölçülmesi ve Değerlendirilmesi. Ankara Üniversitesi Matbası, 1. Baskı, Ankara, 2015.

20. Cronbach LJ. Essentials of psychological testing. 4th Edn. New York: Harper \& Ro, 1984.

21. Epstein R M. Medical Education -Assesment in medical education. N Engl J Med 2007; 356: 387-96.

22. Burrows RS. Understanding self-assessment in undergraduate dental education. British Dent J 2018;224: 897900.

23. Kiehl C, Simmenroth-Nayda A, Goerlich Y, Entwistle A, Schiekirka S, Ghadimi BM. Standardized and qualityassured video-recorded examination in undergraduate education: informed consent prior to surgery. J Surg Res. 2014; 191: 64-73.

24. Landes CA, Hoefer S, Schuebel F, Ballon A, Teiler A, Tran A. Long-term prospective teaching activity of practical skills training and a first OSCE in cranio maxillofacial surgery for dental students. J Craniomaxillofac Surg. 2014; 42: 97-104.

25. Larsen DP, Butler AC, Roediger HL. Test-enhanced learning in medical education. Med Educ. 2008;42:959-66.

26. Larsen DP, Butler AC, Roediger HL. Repeated testing improves long-term retention relative to repeated study: a randomised controlled trial. Med Educ. 2009; 43: 1174-81.

27. Roediger HL, Butler AC. The critical role of retrieval practice in long-term retention. Trends Cogn Sci. 2011; 15: 20-7.

28. Kromann CB, Jensen ML, Ringsted C. The effect of testing on skills learning. Med Educ. 2009; 43: 21-7.

29. van der Vleuten $\mathrm{C}$. The assesment of professional competence: developments, research and practical implications. Adv Health Sci Educ Theory Pract 1996; 1: 41-67.

30. R€uttermann S, Sobotta A, Hahn P, Kiessling C, H€artl A. Teaching and assessment of communication skills in undergraduate dental education - a survey in Germanspeaking countries Eur J Dent Educ 2017; 21: 151-8.

31. Wass V, van der Vleuten, C Shatzer J, Jones R. Assessment of clinical competence. Lancet 2001; 357: 945-9.

32. Birenbaum M, Breuer K, Cascallar E, Dochy F, Ridgway J, Dori J et al. A learning integrated assessment system. EARLI (European Association for Research on Learning and Instruction) series of position papers, 2005.

33. Turgut MF. Eğtimde ölçme ve değerlendirme metotları. (3. Baskı). Ankara: Saydam Matbaacılık, 1984.

34. Hale J. A Better Way to Measure Soft Skills. TD Magazine 2018; 72: 61-4.

35. Crocker L, Algina J. Introduction to classical and modern test theory. New York: Harcourt Brace, 1986. 
36. Aiken LR. Rating scales and checklists: Evaulating behavior, personality, and attitudes. Canada: John Wiley \& Sons, Inc., 1996.

37. Baykul Y. Eğtimde ve psikolojide ölçme: Klasik test teorisi ve uygulaması. Ankara: ÖSYM Yayınları, 2000.

38. Lichtenstein NV, Haak R, Ensmann I, Hallal H, Krämer K, Krause F et al. Does teaching social and communicative competences influence dental students' attitudes towards learning communication skills? A comparison between two dental schools in Germany. GMS J Med Educ 2018; 35: 1-18.

39. Lichtenstein NV, Ensmann I, Haak R, Hallal H, Kupke J, Matthes J et al. "May I help you?" - Evaluation of the new student service at the reception desk during the clinical courses at the Department of Operative Dentistry and Periodontology as a part of a longitudinal curriculum of social and communicative competences for dental students. GMS Z Med Ausbild. 2015; 32: Doc31.

40. Rees C, Sheard C, Davies S. The development of a scale to measure medical students' attitudes towards communication skills learning: the Communication Skills Attitude Scale (CSAS). Med Educ. 2002; 36: 141-7.

41. Laurence B, Bertera EM, Feimster T, Hollander R, Stroman C. Adaption of the Communication Skills Attitude Scale (CSAS) to Dental Students. J Dent Educ. 2012; 76: 1629-38.

42. Bitter K, R€uttermann S, Lippmann M, Hahn P, Giesler M. Self-assessment of competencies in dental education in Germany - a multicentred survey. Eur J Dent Educ 2016; 20: 229-36.

Yazışma Adresi:

Prof. Dr. Funda AKALTAN

Ankara Üniversitesi Diş Hekimliği Fakültesi

Protetik Diş Tedavisi Anabilim Dalı

Beşevler 06560, Ankara

E-posta : akaltanfunda@gmail.com 